\title{
Review on: Effect of Seed Storage Period and Storage Environment on Seed Quality
}

\author{
Birhanu Gebeyehu \\ Plant Science Department, Faculty of Agriculturey, Mekdela Amba University, Mekdela, Ethiopia
}

Email address:

birhanugebeyehu1@gmail.com

\section{To cite this article:}

Birhanu Gebeyehu. Review on: Effect of Seed Storage Period and Storage Environment on Seed Quality. International Journal of Applied Agricultural Sciences. Vol. 6, No. 6, 2020, pp. 185-190. doi: 10.11648/j.ijaas.20200606.14

Received: September 25, 2020; Accepted: October 30, 2020; Published: December 31, 2020

\begin{abstract}
Seed quality deterioration is inevitable process. Since seed is a vital input in agriculture which determines not just the production but also the productivity, it is crucial to maintain the seed quality as well as seed vigor during the storage. Storage is a basic practice in the control of the physiological quality of the seed and is a method through which the viability of the seeds can be preserved and their vigor kept at a reasonable level during the time between planting and harvesting. Many researches on seed storage period have been investigated that seeds can be stored for short period is found in least deterioration. In contrast changes associated with seed deterioration are depletion in food reserve, increased enzyme activity, increased fat acidity and membrane permeability. As the catabolic changes continue with increasing age, the ability of the seed to germinate is reduced. Gradual decrease in the seed quality parameters were observed, as the storage period increase. It is estimated that good quality seeds of improved varieties alone can contribute about 18 to 20 per cent increase in crop yield keeping all the other inputs constant. Lastly using seeds as planting material which stored with in short period of time and in proper environment is very important.
\end{abstract}

Keywords: Seed Quality, Storage Period, Storage Environment

\section{Introduction}

\subsection{Background of the Review}

There are many factors that affect seed quality such as insects, temperature and all biotic and biotic factors [40]. Storage period of seed is most widely important factor, which affects seed quality. Seed moisture content goes up gradually during storage reducing seed quality depending on reduction in germination percentage. But at $15.5 \%$ moisture level invasion of rough rice by storage fungi and germination percentage reduction were proportional to increasing moisture content and the increasing length of storage. Rough rice was infected at moisture content of $13.4 \%$ to $13.8 \%$ within 413 days of storage causing reduction in germination percentage. Lack of availability of quality seeds led to a decline in production caused by the use of low-quality seeds and adaptation in the field is reduced [20]. Availability of quality seeds is related to seed storage. Good handling during storage period can minimize physical damage to the seed, especially seed quality during storage [17].
According to researchers the principal purpose of seed storage is to preserve storage temperature and moisture content on the vigor of economic crops from one season to another [12]. For instance: Storage Welsh onion seeds, after two years storage, the seed temperature and moisture content are the most important quality declined as storage temperature and seed moisture factors affecting seed longevity, with seed moisture content increased. The effects of storage period usually being more influential than temperature on viability and vigor of onion seeds were studied. Many investigators reported that a complete pattern of loss in viability in seed quality is largely dependent on long storage period, and it could be understood on the basis of seed moisture and temperature, relative humidity, storage temperature and concluded that adoption of length of storage, type of seed and seed quality [4].

However storage is a basic practice in the control of the physiological quality of the seed and it is a method through which the viability of the seeds can be preserved and their vigour kept at a reasonable level during the time between planting and harvesting [5]. A few scholars can be concluded 
that amaranth seed can be stored safely for up to sixteen months with over $70 \%$ viability at a temperature range of 15.1 to $20.3^{\circ} \mathrm{C}$ and relative humidity of 26.9 to $50.7 \%$ [2]. A long-term storage of seeds, especially under unfavorable conditions, leads to loss of viability. The nature of this physiological damage is variable, e.g. short-term deterioration in the field is different from long term deterioration during storage, which in turn is different from mechanical damage [13].

Seed storage period may affect the viability of seeds, as the reduction in seed viability is directly proportional to the increase of time [9]. This is because it allows the ripening embryo storage period and further accumulation of food that lasts for storage before germinating, these activities led to an increase in the metabolic processes in the seed. As a result, the seed has decreased viability and cannot germinate optimally, because energy has been used in the metabolic process [6]. In addition to a storage period of seed, seed viability was also influenced by seed storage environments such as temperature and relative humidity [38]. The seeds stored at low temperature storage germinated higher than those stored at high temperatures storage in all storage period [22]. It because the seeds are stored in high temperatures increase the respiration rate and enzyme activity resulting in the overhaul of food reserves before the seeds germinate, the seeds decreased vigor and physical quality of seed.

\subsection{Objective of the Review}

To review the effects of seed storage period and storage environment on seed quality.

\section{Review of Literatures and Discussions}

\subsection{Definitions of the Terms}

Seed: It is defined as a complex biological structure consisting of a plant in miniature and food reserves protected by covering coats. A miniature plant possessing a remarkable capacity to ensure that the new individual starts life in the right place at the right time [24].

Seed quality: Seed quality is judged by different end users such as farmers and industries. For instance, farmers expect to obtain high quality seeds that are able to germinate and produce normal seedlings under field conditions [21].

Seed storage: may be defined as the preservation of viable seeds from the time of collection until they are required for sowing [18]. Seeds are considered to be in storage from the moment they reach physiological maturity until germination [32].

\subsection{Effect of Seed Storage Period and Storage Environment on Seed Quality}

Farmers in the developing world still store their produce including seed under the ambient environment in longer period of time this has been observed to affect seed quality in general and germination in particular [28]. Decrease of seed quality is due to longer seeds storage period increases connected with bio-chemical changes in physiology of seed such as due to auto oxidation of lipids and the increase of the content of free fatty acids these leads to a quick deterioration [31]. According to report, final germination percentage, germination index percentage, energy of germination percentage and emergence rate percentage were decreased as storage periods were increased [37]. The results revealed that before storage treatments significantly exceeded the other storage periods in final germination percentage, germination index percentage, energy of germination percentage and emergence rate percentage followed by that storage after 3 months. While, after 12 months from storage recorded lowest final germination percentage, germination index percentage, energy of germination percentage and emergence rate percentage. It could be concluded that increasing storage periods from 3, 6, 9 and 12 months decreased final germination percentage by $3.11,9.91,18.87$ and $25.80 \%$, respectively compared with final germination percentage of pre storage treatment. Increasing storage periods from 6,9 and 12 months decreased germination index percentage by 6.51 , 15.34 and $26.40 \%$, respectively, compared with germination index percentage after 3 months. Increasing storage periods from 3, 6, 9 and 12 months decreased energy of germination percentage by $11.06,15.63,38.38$ and $48.47 \%$, respectively compared with energy of germination percentage of pre storage treatment. Increasing storage periods from 3, 6, 9 and 12 months decreased emergence rate percentage by 5.73 , $11.51,24.44$ and $33.42 \%$, respectively compared with emergence rate percentage of pre storage treatment.

Result worked on soybean; one of the major constraints to the production of soybean in the tropics is the rapid loss of seed viability and vigour during storage under ambient conditions [27]. The loss of germination is much more acute under tropical conditions [36]. Because Seed viability is the ability of the embryo to germinate and it is affected by a number of factors including temperature, light, oxygen, and water and species type. Germinability which is determined by germination percentage is the proportion of seeds that germinate from seeds subjected to the right conditions for growth while the germination rate is the speed with which the seeds germinate and is affected by seed viability, dormancy and environmental effects that impact on the seed and seedling [44]. Seed deterioration is also associated with storage duration according to report of [35]. Changes associated with seed deterioration are depletion in food reserve, increased enzyme activity, increased fat acidity and membrane permeability. As the catabolic changes continue with increasing age, the ability of the seed to germinate is reduced. Furthermore shrinking and breaking of seeds during storage are some of the physical changes that occurred in soybean seed in storage [26].

As seed quality deteriorates during storage, vigour declines before loss in standard germination [30]. Moreover, reported that farmers in the developing world still store their produce including seed under the ambient environment [15]. Some researchers concluded that, storage under ambient conditions has been observed to affect seed quality in general and 
germination in particular [11]. Storage is improved under ambient conditions if seeds are well-packaged [23]. Irrespective of initial seed quality, unfavourable storage conditions, particularly temperature and relative humidity, contribute to accelerating seed deterioration in storage [14]. Germination and seedling vigour are severely affected if seed is stored at high relative humidity and deterioration is much faster if the storage temperature is also high [10].

Scholars worked on different varieties of tef and reported that, germinating percentage of the seeds had declined when storage period elongates [42]. It is also noted the presence of variation in germination capacity among varieties when the storage period increases. The germination percentage falls in the range of $89 \%$ for Asgori variety stored for 31 months to $96 \%$ for Tsedey and Magna variety seeds stored for 7 months. Germination percentage was reduced by $1.6 \%$ as the storage period extended from 7 months to 19 months whereas further storage to 31 months had reduced germination of the seed by $3.7 \%$. The result indicates all the varieties responded with a reduction in germination percentage when the seed storage period increased beyond 7 months. The germination capacity of Tsedey variety had deteriorated significantly when the storage period elongates to 31 months. Similarly Asgori variety had been significantly altered by seed storage period in higher degree. More over storage period had a negative influence on seed germination rate. After a year of storage, seed germination rates of all three genotypes declined significantly. After 12 months of storage, the average value of the tested parameter $(89.03 \%)$ was statistically highly significantly lower than the other storage periods examined. However, on sunflower observed that no effect of storage period on seed germination and other seed quality parameters [16].

Researches worked on maize parental lines and reported that; significant variations were observed among and within parental lines for germination and emergence percentage as well seedling traits in different storage period [8]. Germination, emergence and fresh weight (shoot and root) were decreased as the seed stored longer duration. This finding demonstrated that seed germination, emergence rate and seedling establishment are decreased with increased in seed storage period [43, 7]. Reporters also added that seed germination declined significantly after one year storage [40]. Moreover; Suggested on boro Rice Variety BRRI dhan47 and reported that; Seed germination and seedling growth parameters were decrease with increase in storage period which might be the cause of attaining dormancy of seed due to increase in storage period [40].

Investigator reported that gradual decrease in the seed quality parameters were observed, germination percentage, speed of germination, seedling length, seedling dry weight and seedling vigor index decreased with the increase in Storage period [31]. The results showed germination percentage, speed of germination, seedling length, seedling dry weight and seedling vigor index were in the decreasing trend as storage periods increased. Results revealed that before storage treatments significantly exceeded the other storage periods germination percentage, speed of germination, seedling length, seedling dry weight and seedling vigor index followed by after 150 days. While, after 250 days from storage recorded lowest germination percentage, speed of germination, seedling length, seedling dry weight and seedling vigor index.

Researchers reported that Teff seeds stored for 7 months had produced longest and vigorous seedlings than seeds stored for 31 months [42]. The result also showed that storing tef seeds beyond 7 months, particularly for 31 months reduce the seedling length by $6.64 \%$. The reduction in seedling length could be attributed due to the depletion of the nutrients in the endosperm because of seed ageing. The current research ad further found that seedling length in tef was influenced by the inherent characteristics of varieties. On the other hand Dukem and Magna variety had significantly longest seedling length while Tsedey had the shortest. Accordingly, Vigour index I had been significantly affected by storage period. Seeds which were stored for 7 month exhibited statistically higher vigour index I from seeds stored for 19 and 31 months. On the other hand, 19 and 31 months stored seeds did not vary statistically. Storing the seed beyond 7 months to 19 months reduce vigour index I by $3.72 \%$. Further extending storage period to 31 months had an effect of reducing vigour index I by $6.39 \%$.

Reports stated that the increasing storage period from 0 to 18 months led to an increase in the value of electrical conductivity of a wheat seed 16.03 to $52.02 \mu$ S.cm [19]. During storage has suffered deterioration as indicated by electrolyte leakage that increases the value of electrical conductivity in soaking water. Moreover, increasing storage period also resulted in germination and dry weight decreased, at the end of the observation of the initial germination percentage decreased from $82.3 \%$ ( 0 months) to $53.6 \%$ (18 months), followed by the number of dead seeds [25]. The statement was in line with the increase in the percentage of dead seeds which from $25.31 \%$ (at 10 months) to $30.16 \%$ (at 12 months).

Reporters reported that all varieties of sorghum were stored at storage room with temperature of $38^{\circ} \mathrm{C}$ and $\mathrm{RH} \pm 48 \%$ for 12 months yielded damage seed was higher than stored for 10 months, by $24.19 \%, 14.73 \%$ [29]. Seed vigor as shown by the percentage of total normal seedling stored at storage room with temperature of $\pm 18^{\circ} \mathrm{c}$ and $\mathrm{RH} \pm 48 \%$ for 12 months was lower than stored at storage room for 10 months, by $59.50 \%$, $78.00 \%$, respectively. Also, the speed germination of seed after store 12 months was lower than it stored at storage room for 10 months, by $36.47 \% /$ day, $24.58 \% /$ day, respectively. Sorghum variety that has the best seedling was Super-1. It was indicated by root length and dry weight of normal seedlings. Research finding worked on storage of Boro rice variety BRRI dhan 47 and Concluded that Seed germination and seedling growth parameters reduced with increasing storage duration due to dormancy of seed [40]. BRRI dhan47 showed the tendency to become dormant after storage. After six months of storage seed germination percentage and seedling growth parameters were almost zero. Seeds that deteriorated rapidly by increasing storage duration generally showed a marked decline in their ability to germinate [1]. 
Research done on perennial rye grass and concluded that seed and seedling traits were affected significantly under effects of storage temperature values of germination, germenablitiy and length of pulmule were increase with increase of storage while the length of radical were increase after the length of 18 months storage [32]. The percentage of dead seeds was highest in soybean seeds stored in the storage period of 60 days after the stored, which is the longest storage time of the study [3]. Researchers ere found similar results to the current experiment on timothy grass seeds which were stored for one, two, three, four and 5 years under ambient storage condition [34]. They had observed that germination of timothy grass seed had sharply declined from $90-95 \%$ on the fresh harvest to $1 \%$ after 5 years. The magnitude of reduction in germination percentage was minimal in seeds stored from 1 year to 2 years; however, subsequent storage periods had severely reduced the germination percentage of timothy grass. Similarly reported that, a significant germination percentage reduction after storage of two varieties of perennial ryegrass for 9 months at different temperatures [33]. According to finding, germination percentage had reduced due to seed storage which had stayed above 9 months and seed germination was affected by storage time and the varietal characteristics in perennial ryegrass [40]. Seed should not be stored for extended periods when there is high temperature and relative humidity [41]. Storing seed beyond of optimum storage period might be resulted in reduces germination potential, seedling establishment and final seed production [38].

\section{Conclusion and Recommendation}

\subsection{Conclusion}

Seed and its quality among others are vital input in crop production. Crop response to other inputs largely depends on the quality of seed. It is estimated that good quality seeds of improved varieties alone can contribute about 18 to 20 per cent increase in crop yield keeping all the other inputs constant Seed germination and vigour are important indicators of quality which are substantially reduced during storage. Seed aging and improper storage environment is recognized by some parameters like delay in germination and emergence, slow growth and increasing of susceptibility to environmental stresses in various periods of storage. Seed quality decreases under long storage conditions due to long seed storage period. It is the reason of declining in germination characteristics. Long seed storage period is manifested as reduction in germination percentage and those seeds that do germinate produce weak seedlings.

\subsection{Recommendation}

Storage is a basic practice in the control of the physiological quality of the seed and is a method through which the viability of the seeds can be preserved and their vigour kept at a reasonable level during the time between planting and harvesting. Seed deterioration starts immediately after a crop has attained the physiological maturity stage. Thus, in order to prevent the quantitative and qualitative losses due to several biotic and abiotic factors during storage, several methods are being adopted such as seed treatment with suitable chemicals or plant products, as well as seed storage in safe environment. As due to the damage in cell membrane and other conditions changes in the seed system, for example, the protein and nucleic acid accumulation. Such degenerative changes result in complete disorganization of membranes and cell organelles and ultimately causing death of the seed and loss of viability. The most widely recognized and predictable ultra-structural changes in all the cell organelles were the loss in integrity of membranes, which constantly leads to increased seed deterioration particularly during storage. So that timely use of a seed than storing seeds longer period of time and controlling seed storage environment is very important.

\section{Acknowledgements}

I express my heartfelt and sincere gratitude to my advisors Dr. Dereje Ayalew for his continuous support, keen guidance, comments and encouragement from the initial stage of title selection to the completion of the write-up of the review paper. A lot of thanks to the Mekdela Amba University for its support for different writing materials and ICT center.

\section{References}

[1] Abdellaoui. A. Kandil A. E. Sharief and M. S. Sheteiwy. (2013). Effect of Seed Storage Periods, Conditions and Materials on Germination of Some Soybean Seed Cultivars American Journal of Experimental Agriculture, 3 (4) 1020-1043.

[2] Adam, B. D., Su, L., Lusk, J. L. and Arthur, F., 2017. Anchoring, information, and fragility of choice experiments: an application to consumer willingness to pay for rice with improved storage management. Journal of agricultural and resource economics, 42 (1835-2017-650), pp. 255-274.

[3] Akter, N., Haque, M. M., Islam, M. R., \& Alam, K. M. (2014). Seed Quality of Stored Soybean (Glycine max L.) as Influenced by Storage Containers and Storage Periods. A Scientific Journal of Krishi Foundation, 12 (1), 85-95.

[4] Amjad, M. and M. A. Anjum, (2002). Effect of relative humidity and ageing period on the quality of onion seed. Int. J. Agri. \& Biol., 1560-8530/04-2-291-296.

[5] Azevedo, M. R. Q. A., Josivanda P. G. G., Dilma, M. M. T. and Vicente, P. Q., (2003). Influência das embalagense condições de armazenamento no vigor de sementes de gergelim. Rev. Bras. Eng. Agríc. Ambient., 7 (3): 519-524.

[6] Badawi, M. A., Seadh, S. E., Abido, W. A. E., \& Hasan, R. M. (2017). Effect of Storage Treatments on Wheat Storage. International Journal of Advanced Research in Biological Sciences, 4 (1), 78-91.

[7] Basra, S. M. A. N; Ahmad, M. M; Khan, N; Iqbal and Cheema, M. A. (2003). Assessment of cotton seed deterioration during accelerated aging. Seed Sci. Technol. 31: 531-540. 
[8] Belay Garoma Temesgen Chibsa Tolera Keno Yirgalem Denbi. (2017). Effect of Storage Period on Seed Germination of Different Maize Parental Lines Journal of Natural Sciences Research Vol. 7, No. 4.

[9] Bortey, H. M., Sadia, A. O., \& Asibuo, J. Y. (2016). Effect of seed storage period and temperature upon seed and seedling traits of pernial rye grass (Lolium pernin L.). polopojerida 21 (2) 3-9.

[10] Cantliffe, J. D. (1998). Seed germination for transplants. Horticulture Technology 8 (4).

[11] Chin, H. F. (1988). Storage and Testing of Forage seeds in the Tropics. Online at seed processing. FAO Technical Guidelines. No. 21. (Eds). Rome. Pp 3, 33-43, 51-53.

[12] Ellis, R. H., Hong, T. D. and Roberts, Y. E., 1991. Effect of storage temperature and moisture on the germination of papaya seeds. Seed Science Research, 1 (1), pp. 69-72.

[13] F Genes and Agnes MS Nyomora (2018). Effect of storage time and temperature on germination ability of escoecaria bussei Tanzania journal of science; 44 (1) 123-133.

[14] Fabrizius, E., Tekroni, D. M., Egli, D. B. and Rucker, M (1999). Evaluation of viability model for prediction soybean seed germination during warehouse storage. Crop Science, 39: 194-201.

[15] Freistritzer, W. P., Vock, H. A., Kelly, F. and Ziger, E. K (1981). Cereal and grain-legume Genbanks voleI principles and methodology international board for plant genetic resource rome. Germinability and Storability of Cowpea (Vigna unguiculata (L) Walp). Journal Agricultural Science, 8 (10), 241-248. https://doi.org/10.5539/jas.v8n10p241.

[16] Ghasemnezhad, A. and Honermeier, B., (2009). Influence of storage conditions on quality and harvesting and storage: An organic seed production manual for seed growers in the.

[17] Goftishu M, Belete K. Susceptibility of sorghum varieties to the maize weevil Sitophilus zeamais Motschulsky (Coleoptera: Curculionidae). African Journal of Agricultural Research. 2014 Jul 29; 9 (31): 2419-26.

[18] Gokhale, D. (2009). Post-harvest Seed Storage/handling. Syngenta Foundation for Sustainable Agriculture. STAK Conference, Nairobi. Pp. 1-11.

[19] Holmes, G. D. and G. Buszewicz. (1958). The storage of seed of temperate forests tree species. Forest. Abstr. 19: 313-322.

[20] Jyoti \& Malik, C. P. (2013). Seed Deterioation. Internasional Journal of Life Sciences Biotechnology and Pharma Reasearch, 2 (3), 374-385.

[21] Khan, N., Kazmi, R. H., Willems, L. A. J., Heusden, A. W. van, Ligterink, W., Hilhorst, H. W. M. (2012). Exploring the natural variation for seedling traits and their link with seed dimensions in tomato. Plant, Cell and Environment. 35, 929-951.

[22] Mbofung, G. C. Y. (2012). Effects of Maturity Group, Seed Composition and Storage Conditions on The Quality and Storability of Soybean (Glycine max (L.) Merrill) seed. Lowa State University, Ames, Lowa.

[23] McCormack, H. J. (2004). Seed Processing and Storage. Principles and Practices of Seed Viability of high and low oleic sunflower seeds. International Journal of Plant Production 3: $39-48$.
[24] McDonald and Copeland, (1998). Seed production principles and practices. mid-Atlantic and Southern US. Pp. 9-17.

[25] Naguib, N. A., Mohamed, E. A. I., \& El- Ai dy, N. A. (2011). Effect of Storage Period and Packaging Material on Wheat (Triticumaestivum L.) Seed Viability and Quality. Journal Agriculture, 89 (4), 1481-1497.

[26] Narayan, R., Chauhan, G. S. and Verma, N. S. (1988a). Changes in the quality of soybean during storage. Part 1- Effect of storage on some physic-chemical properties of soybean. Food Chemistry, Vol. 27, No. 1, pp. 12-23.

[27] Nkang, A. and Umho, E. O. (1996). Six month storability of five soybean cultivars as influenced by stage of harvest, storage temperature and relative humidity. Seed Science and Technol., 25: 93-99.

[28] Isaac, E. A. Seweh, S. Apuri, B. K. Banful and S. Amoah, (2016). Effect of Storage Periods on Seed Quality Characteristics of Three Soybean (Glycine $\max (\mathrm{L})$ Merrill) Varieties, international journal of scientific research engenering and technology, 2 (4) 823-830.

[29] Paul B. Timotiwu, Eko Pramono Agustiansyah and Ni Wayan Ayung Surya Asih, (2017). Effect of Storage Periods on Physical Quality and Seed Vigor of Four Varieties of Sorghum (Sorghum Bicolor [L.] Moench) Research in Agriculture Vol. 2, No. 2.

[30] Pratt, P., Bolin, P. and Godsey, C. (2009). Soybean Production Guide. Oklahoma Cooperative Extension Service, Division of Agricultural Sciences and Natural Resources, Oklahoma State University. Pp. 12-114.

[31] Ramya M. J., Kulkarni, G. U. and Deepthi R (2018). Effect of Packaging Material, Storage Conditions and Storage Period on Seed Quality Parameters of Sesame (Sesamum indicum L.), Int. J. Pure App. Biosci. 6 (5): 309-313.

[32] Raoudha Abdellaoui, Aymen Souid, Dhikra Zayoud and Mohamed Neffati, (2013). Effects of natural long storage duration on seed germination characteristics of Periploca angustifolia Labill. frican Journal of Biotechnology Vol. 12 (15), 1760-1768.

[33] Rozman valtaka, Gordana Bulkive, Anita Liska, Renta Belcivike, (2010). Differences in traits seeds and seedlings of pernial rye grass cultivare after nine mountorage at different temperature Napoca 38 (1) 155-158.

[34] Rysard J. and Goerck Dorta, (1989). The vigour of timothy (phelum peretenese L.) sees stored up to 5 years actasocieties botanicrum polonie 58 (2), 263-272.

[35] Shelar, V. R. (2007). Strategies to Improve the Seed Quality and Storability of Soybean A Review. Seed Technology Research Unit (NSP), Mathtme Phule Krighi Vidyprth, Rahuri 413- 722, India. Agricultural Review, 28 (3): 188-196.

[36] Shelar, V. R., Shaikh, R. S. and Nikam, A. S. (2008). Soybean seed quality during Storage: A Review. Agric. Rev., 29 (2): 125-131.

[37] Sheteiwy, M. S., Kandil, A. A., and Sharief, A. E., 2013. Effect of seed storage periods, conditions and materials on germination of some soybean seed cultivars. American Journal of Experimental Agriculture, 3 (4), p. 1020.

[38] Sisman C. (2005). Quality losses in temporary sunflower stores and influences of storage conditions on quality losses during storage. Journal of Central European Agriculture. 6: 143-150. 
[39] Strelec, I. P. R., Ivanisic, I. J. V., Jurkovic, Z., Ugarcic-Hardi, Z., \& Sabo, M. (2012). Influence of Temperature and Relative Humidity on Grain Moisture, Germinationand Vigour of Three Wheat Cultivars During One Year Storage. J. Poljoprivreda, 16 (2), 20-24.

[40] Sultana, N. Ali Y, Jahan, S. and Yasmin, S. (2016). Effect of Storage Duration and Storage Devices on Seed Quality of Boro Rice Variety BRRI dhan47. J Plant Pathol Microbiol 8: 392. doi: 10.4172/2157-7471.1000392.

[41] Technical Guidelines for Standards and Procedures, FAO. (2006). Plant Production and Protection Paper 185 Rome Italy.
[42] Teshager A, Wasu M, Kebebew A. (2016). Effect of Seed Storage and Varieties on Seed Quality of Tef [Eragrostis tef (Zucc.) Trotter]. Agri Res \& Tech: Open Access J. 2 (4): 555-593.

[43] Verma, S. S. U and Tomer, R. P. S. (2003). Studies on seed quality parameters in deteriorating seeds in Brassica (Brassica Campestris). Seed Sci. Techno. 31: 389-396. www.fao.org.AG/AGP.doc.PUBLC.pdf.

[44] Zamora FJH. (2014). Effect of moisture on lentil seed germination and growth. http:// en.wikipedia.org/wiki/Germination. 